\title{
UPWELLING CHARACTERISTICS IN THE SOUTHERN JAVA WATERS DURING STRONG LA NINA 2010 AND SUPER EL NINO 2015
}

\section{KARAKTERISTIK UPWELLING DI PERAIRAN SELATAN JAWA PADA TAHUN STRONG LA NINA 2010 DAN SUPER EL NINO 2015}

\author{
Agus S. Atmadipoera ${ }^{*}$, Agitha S. Jasmine ${ }^{2}$, Mulia Purba ${ }^{1}, \&$ \\ Anastasia R.T.D. Kuswardani ${ }^{3}$ \\ ${ }^{1}$ Department of Marine Science and Technology, IPB University, Bogor, 16680, Indonesia \\ ${ }^{2}$ Master Program of Maritime Technology, IPB University, Bogor, 16680, Indonesia \\ ${ }^{3}$ Center for Research and Development of Marine and Coastal Resources, Ministry of \\ Marine Affairs and Fisheries, Jakarta, 14430, Indonesia \\ * E-mail: atmadipoera_itk@apps.ipb.ac.id
}

\begin{abstract}
Seasonal coastal upwelling in the Southern Java waters is considered to be modulated by interannual ocean-atmosphere variability of El Nino Southern Oscillation (ENSO). This study aims to investigate a contrast in seasonal upwelling characteristics during the La Nina 2010 and El Nino 2015 events, by using multi-datasets from INDESO model output and satellite-derived datasets. Distinct characteristics of seasonal upwelling was clearly seen. In La Nina, surface ocean-atmosphere variables were much lower than that observed in El Nino, except for precipitation rate, sea surface temperature, and sea surface height. In La Nina, warmer $\left(27-28^{\circ} \mathrm{C}\right)$ and a very freshwater $(<33.80 \mathrm{psu})$ were predominant in the upper $45 \mathrm{~m}$ depth, concealing upwelling cooler water at subsurface. In contrast, in the El Nino, a drastic upwelled subsurface water of isotherms of $25-26^{\circ} \mathrm{C}$ and isohalines of $34.24-34.44 \mathrm{psu}$ were outcropped at the sea surface. Temperature-based upwelling index is $-2^{\circ} \mathrm{C}$ and $+4^{\circ} \mathrm{C}$, demonstrating the ENSO has strongly modulated the upwelling intensity. A strong eastward South Java Coastal Current (SJCC) was found only in La Nina event. Persistent westward Indonesian Throughflow south of $9.5^{\circ} \mathrm{S}$ were visible both in different ENSO events. Estimate of Ekman transport derived from model meridional current was intervened strongly by the presence of the SJCC and the ITF.
\end{abstract}

Keywords: ENSO event, multi-datasets, seasonal upwelling, South Java waters, upwelling index

\begin{abstract}
ABSTRAK
Upwelling pantai musiman di perairan Selatan Jawa diduga dapat dimodulasi oleh variabilitas antartahunan laut-atmosfer El Nino Southern Oscillation (ENSO). Penelitian ini bertujuan untuk menganalisis perbedaan karakteristik upwelling musiman selama kejadian La Nina 2010 dan El Nino 2015, berdasarkan multi-dataset dari keluaran model INDESO dan dari data satelit. Karakteristik yang berbeda dari upwelling musiman terlihat jelas. Di La Nina, variabel laut-atmosfer permukaan jauh lebih rendah daripada yang diamati di El Nino, kecuali untuk tingkat curah hujan, suhu permukaan laut, dan tinggi permukaan laut. Di La Nina, air laut yang lebih hangat $\left(27-28^{\circ} \mathrm{C}\right)$ dan lebih tawar $(<33,80 p s u)$ mendominasi di atas lapisan kedalaman $45 \mathrm{~m}$, yang menahan air dingin upwelling tetap di bawah permukaan. Sebaliknya, di El Nino, air bawah permukaan naik secara drastis dari isoterm $25-26^{\circ} \mathrm{C}$ dan isohalin dari 34,24-34,44psu tersingkapkan di permukaan laut. Indeks upwelling berbasis suhu adalah $-2^{\circ} \mathrm{C}$ dan $+4^{\circ} \mathrm{C}$, menunjukkan ENSO telah sangat memodulasi intensitas upwelling. Arus Pantai Selatan Jawa (SJCC) yang kuat mengalir kearah timur hanya ditemukan pada kejadian La Nina. Aliran Arlindo yang persisten di selatan 9, $5^{\circ} \mathrm{S}$ terlihat pada ENSO berbeda. Perkiraan angkutan Ekman yang diturunkan dari model arus meridional telah diintervensi secara kuat oleh kehadiran SJCC dan Arlindo.
\end{abstract}

Kata kunci: indeks upwelling, kejadian ENSO, multi-datasets, Selatan Jawa, upwelling musiman 


\section{INTRODUCTION}

The Southern Java waters is located in the northeastern Indian Ocean where the local ocean dynamics and variability are influenced by large-scale circulation from the remotely forced equatorial Indian Ocean, expressed by the eastward South Java Coastal Current (SJCC), and from the persistent westward flows of the Indonesian Throughflow outflowing from the main outflow straits (Quadfasel \& Cresswell, 1992; Sprintall et al., 1999; Atmadipoera et al., 2009) (Figure 1). This region is also situated between the continents of Asia and Australia which are strongly influenced by the monsoon wind system and the IndoPacific ENSO/IODM phenomena (Susanto et $a l .$, 2001). The monsoon winds system in this region is characterized by seasonal reversals of wind direction (Figure 1). During the Southeast Monsoon (SEM), the southeasterly winds from Australia generate upwelling system in the Southern Java (Susanto et al., 2001; Tubalawony, 2008). Upwelling is defined as physical processes of vertical movement of water mass from the deeper layer to surface layer which is influenced by the association of local winds with the monsoon system (Ratnawati et al., 2016; Kuswardani \& Qiao, 2014). Between December and March (during the Northwest Monsoon, NWM), the northwesterly winds blow, while from June to October (the SEM period) the southeasterly monsoon winds blow.

On interannual time-scale, the Southern Java waters is also strongly influenced by the ENSO (El Nino Southern Oscillation) and also the Indian Dipole Mode phenomena (Kunarso et al., 2012), which affect seawater temperature changes during the El-Nino and La-Nina periods. This variation also influences upwelling intensity in southern Java. Susanto et al. (2001) reported that the intensity of coastal upwelling strengthened during El Nino was associated with the southeast monsoon and weakened when La Nina was associated with the northwest monsoon. Upwelling event is indicated by a decrease in temperature, an increase in salinity and an increase in the number of nutrients on the surface that have an impact on water fertility and primary productivity (Rosdiana et al., 2017; Atmadipoera et al., 2018, Utama et al., 2017). When El Nino occurs, the upwelling duration tends to be longer and the intensity increases, resulting in higher primary productivity compared to other 'normal' and La Nina years (Kemili \& Putri, 2012).

Information of spatial-temporal variability of sea surface temperature (SST) and salinity provides an important role in the field of fisheries to identify the phenomenon of upwelling/downwelling, determining the location of the front of water masses or eddies current (Jumars, 1994; Wardani et al., 2013). Gaol et al. (2002) examined the effect of ENSO and IOD on the production of Lemuru and tuna fishing. ENSO also influences the water mass flow carried by the Arus Lintas Indonesia (ARLINDO) current system from the Pacific to the Indian Oceans. Kuswardani \& Qiao (2014) found that ENSO contributed to the mass flow of ARLINDO water that played a role in the formation of upwelling in eastern part of Southern Java waters. At the time of El Nino, there was a decrease in the volume of water mass transport that affected water temperature fluctuations, and vice versa in the La Nina period (Susanto et al., 2001).

The objective of this study is to investigate the contrast of upwelling characteristics during the ENSO period, by analyzing the physical parameters of oceanatmosphere in the Southern Java waters. The ENSO index showed a strong La Nina event occurred in 2010 and super El Nino event was in 2015 (NOAA Climate Prediction Center, 2015). Modeling study of upwelling in Maluku Sea suggested that super El Nino 2015 has strongly modulated coastal upwelling there (Atmadipoera et al., 2018). In this study, the ENSO index is determined 
from the NINO3.4 index that is the SST anomaly in the western and central equatorial Pacific regions. The amplitude of the NINO3.4 index was minimum (maximum) during the 2010 La Nina (2015 El Nino) index which occurred between the period of July-October (NOAA Climate Prediction Center, 2015). Here, the daily averaged temperature, salinity, zonal and meridional current components datasets in August 2010 and in August 2015 from a high-resolution $1 / 12^{\circ}$ ocean general circulation model of INDESO were chosen to represent a contrast of upwelling characteristics. It is also noted that only ENSO events were considered, as a main forcing for interannual ocean variability, but excluding the IODM phenomena.

\section{RESEARCH METHODS}

\subsection{Study Area}

The study area is located in the Southern Java waters (Figure 1, dashed white rectangle), covered geographical coordinates between $7.6^{\circ} \mathrm{S}-12^{\circ} \mathrm{S}$ and $105.4^{\circ} \mathrm{E}-114^{\circ} \mathrm{E}$. The sampling box of time-series data (seawater temperature, salinity, current) in the onshore location is at $8.33^{\circ} \mathrm{S}$ and $110^{\circ} \mathrm{E}$ (small black rectangle), and in the offshore location (small

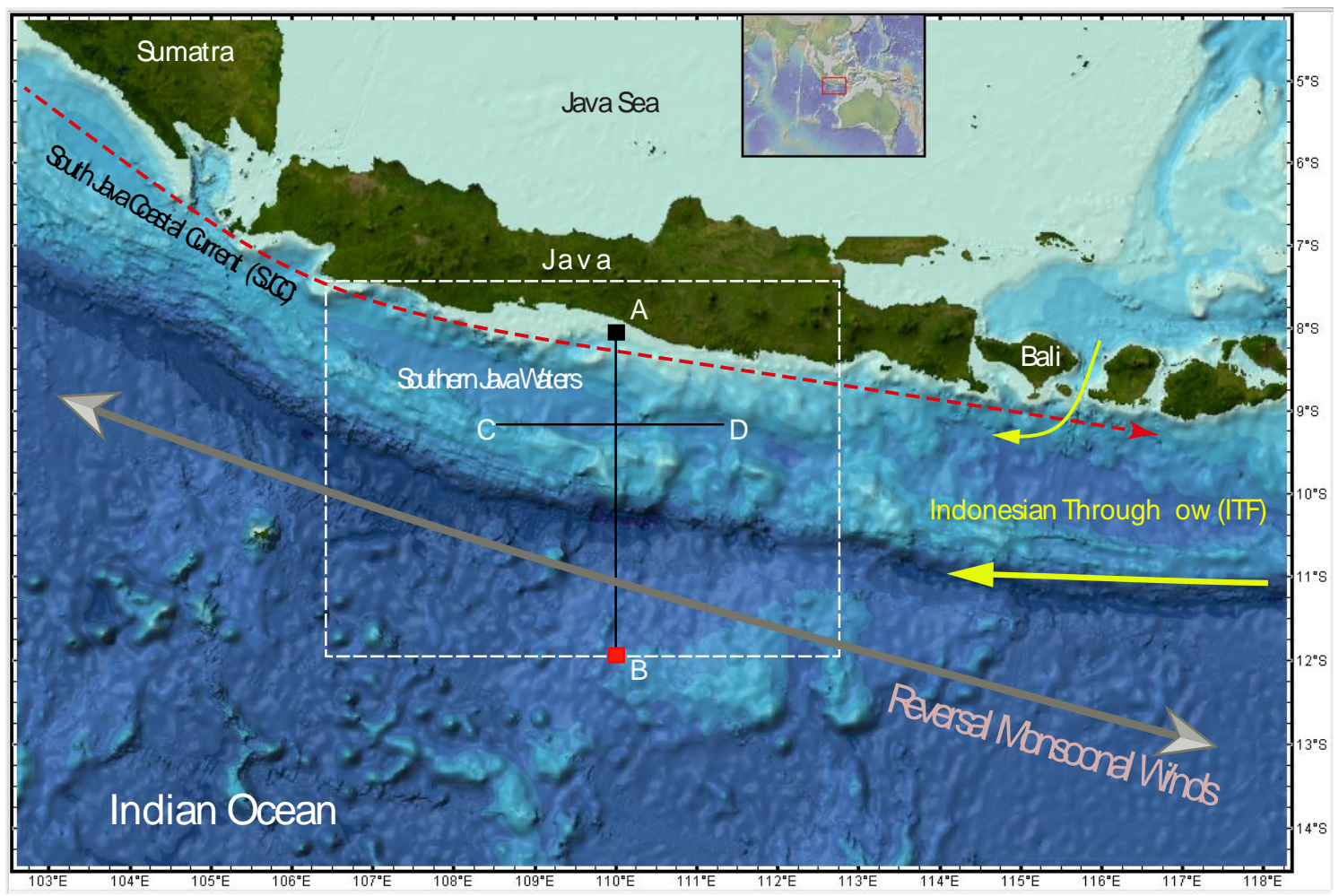

Figure 1. The study area in the Southern Java Waters (dashed white rectangle). Line A-B denotes for depth-latitude plot of monthly averaged parameters in August. Line C$\mathrm{D}$ denotes for calculation of transport volume. Small black (red) rectangle is box sampling point for extraction of time-series data in the onshore (offshore) location, and also for calculation of temperature-based upwelling index (TUI), defined as the difference of sea surface temperature at B (offshore) and at A (onshore). The eastward flow of South Java Coastal Current (SJCC) is indicated by dashed red arrow along western Sumatera - Southern Java; yellow arrows are westward flow of Indonesian Throughflow (ITF); and thick grey double-head arrow is seasonal reversal Monsoonal winds (the Southeasterly and the Northwesterly winds) over the region. 
red rectangle) is at $12^{\circ} \mathrm{S}$ and $110^{\circ} \mathrm{E}$. Line transect of A-B is depth-latitude section at $110^{\circ} \mathrm{E}$ between $8^{\circ} \mathrm{S}-12^{\circ} \mathrm{S}$ for monthly averaged of temperature, salinity and meridional current component, while line transect of C-D is for transport volume calculation during different ENSO event. The influence of ENSO from the Pacific Ocean to the Southern Java waters was carried out by analyzing the ENSO index, referred to Nino3.4 (NOAA Climate Prediction Center, 2015). Anomaly of surface temperature of $\pm 0.5^{\circ} \mathrm{C}$ is used as a threshold, where the index above $+0.5^{\circ} \mathrm{C}$ is the $\mathrm{El}$ Nino event while the index below $-0.5^{\circ} \mathrm{C}$ is the La Nina event.

\subsection{Data and Data Analysis}

Time series of model temperature, salinity and meridional current component are daily averaged datasets, obtained from high-resolution 3-dimension ocean general circulation model output of the INDESO model in 2010 and 2015. The model simulation has been performed by CLS Toulouse France. Daily winds field datasets were downloaded from the European Center in 2010 and 2015, and pentad surface precipitation rate was obtained from the CMAP data center based on calculation procedure of Xie \& Arkin (1997). The model sea surface temperature data are validated by sea surface temperature derived from the Aqua Modis satellite data. The INDESO model datasets were processed using Pyferret under Ubuntu Linux operating system. The data used in this study were daily averaged datasets of temperature, salinity and meridional current component during period of La Nina (2010) and El Nino (2015). Transport volume in the upper $50 \mathrm{~m}$ depth is calculated based on the formula used by Atmadipoera \& Hasanah (2017), as follows:

\section{Transport volume \\ $=\int_{x 1}^{x 2} \int_{z}^{0} v(x, z) d z d x$}

where, water transport volume is calculated in Sverdrup (Sv) $\left(1 \mathrm{~Sv}=10^{6} \mathrm{~m}^{3} / \mathrm{s}\right)$ over a horizontal distance between $x 1$ and $x 2(\mathrm{~m})$ from depth $(\mathrm{z}=50 \mathrm{~m})$ to the sea surface $(0$ $\mathrm{m})$, and $v(x, z)$ is meridional current component $(\mathrm{m} / \mathrm{s})$ at distance $x(\mathrm{~m})$ and depth $z(\mathrm{~m})$.

The temperature-based Upwelling Index (TUI) is calculated from the difference between sea surface temperature at the offshore area and at onshore area at the same longitude, as modified from Benazzouz et al. (2014). Location near the coast was chosen at $110^{\circ} \mathrm{E}$ and $8^{\circ} \mathrm{S}$, while in the offshore was chosen at $110^{\circ} \mathrm{E}$ and $12^{\circ} \mathrm{S}$. A high index value indicates a strong upwelling event and vice versa. The temperature-based upwelling index equation is expressed (Benazzouz et $a l ., 2014)$, as follows:

$$
\begin{aligned}
& \mathrm{TUI}_{\mathrm{SST} \text { (lon,time) }}=\mathrm{SST}_{\text {offshore(lon,time) }}- \\
& \text { SST }_{\text {inshore(lon,time) }}
\end{aligned}
$$

The contrast of amplitude of TUI is evaluated from the data-series during the SEM 'upwelling' period (May-October) in the study area, both in the 2010 La Nina and 2015 El Nino years.

Validation between model and satellite data were done by using a simple linear correlation formula, as described by Thomson \& Emery (2014), as follows:

$r=\frac{1}{N-1} \sum_{i=1}^{N} \frac{\left(x_{i}-\vec{x}\right)\left(y_{i}-\vec{y}\right)}{s_{x} s_{y}}$

where, $r$ is correlation coefficient (between 1 and +1$) ; N$ is number of data; $x_{i}, y_{i}$ is the $i^{\text {th }}$ $x$ and $y$ data; $\bar{x}, \bar{y}$ is average of $\mathrm{x}$ and $\mathrm{y} ; s_{x}, s_{y}$ is standard deviation of $\mathrm{x}$ and $\mathrm{y}$ data.

Correlation analysis was performed to inspect how closely the two variables of time-series data (model temperature and satellite derived temperature) are displayed. Model temperature and sea surface temperature data from satellite imagery used 

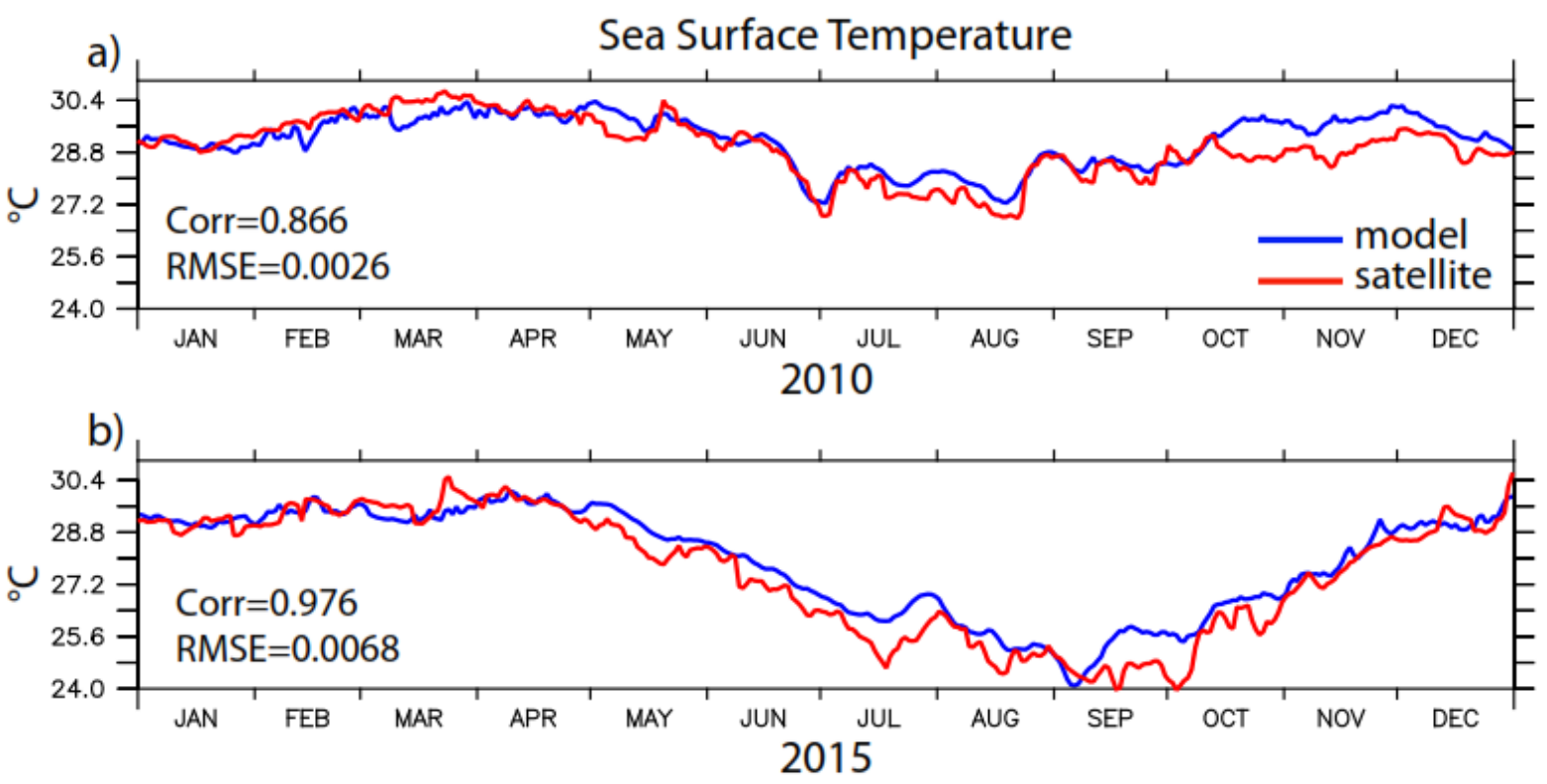

Figure 2. Comparison of model and satellite-derived sea surface temperature in the study area in 2010 and 2015. Red curve denotes for satellite-derived SST and blue curve for model SST. Correlation coefficient is 0.866 and 0.976 , respectively.

in validation are daily composite data for one year of observation in 2010 and 2015. Timeseries data of sea surface temperature from model and satellite at same location shows a good agreement with correlation coefficient of 0.866 and 0.976 (Figure 2). It is highlighted that the model reproduced well in describing the results of satellite-derived sea surface temperature observation, even though the model showed an underestimate for the minimum temperature during the SEM period in July-September 2015. High correlation shows that the model has good accuracy for further analysis and represents conditions that are closed to reality in the study area with small root-mean-squarederrors of about 0.0026 and 0.0068, respectively (Figure 2).

In addition, model output datasets from INDESO have been intensively validated with available observed datasets, such as moored buoys, CTD Argo floats, satellite derived data, and hydrographic data, in which the INDESO model output datasets were in good agreement with the observed ones (Tranchant et al., 2015).

\section{RESULTS AND DISCUSSION}

\subsection{Contrast of Surface Atmosphere- Ocean Variables During La Nina and El Nino}

Comparison of surface oceanatmosphere conditions in the upwelling region in the Southern Java waters during the 2010 La Nina event (hereinafter referred to the La Nina event) and the 2015 El Nino event (hereinafter referred to the El Nino event) is shown in Figure 3. Surface atmosphere is represented by variables of eastward wind speed, wind stress curl, and rate of precipitation (Figure 3 a-b-c). Seasonal reversal monsoon wind is clearly seen from zonal (eastward) wind component, where the SEM period is associated with the negative zonal winds from May to November, and the NWM is positive zonal wind from December to April, with local fluctuations over the time-series (Figure 3a). Negative (westward) wind speed during El Nino was much stronger and persistent between -6 and $-9 \mathrm{~m} / \mathrm{s}$, compared to those appeared in La Nina event. 

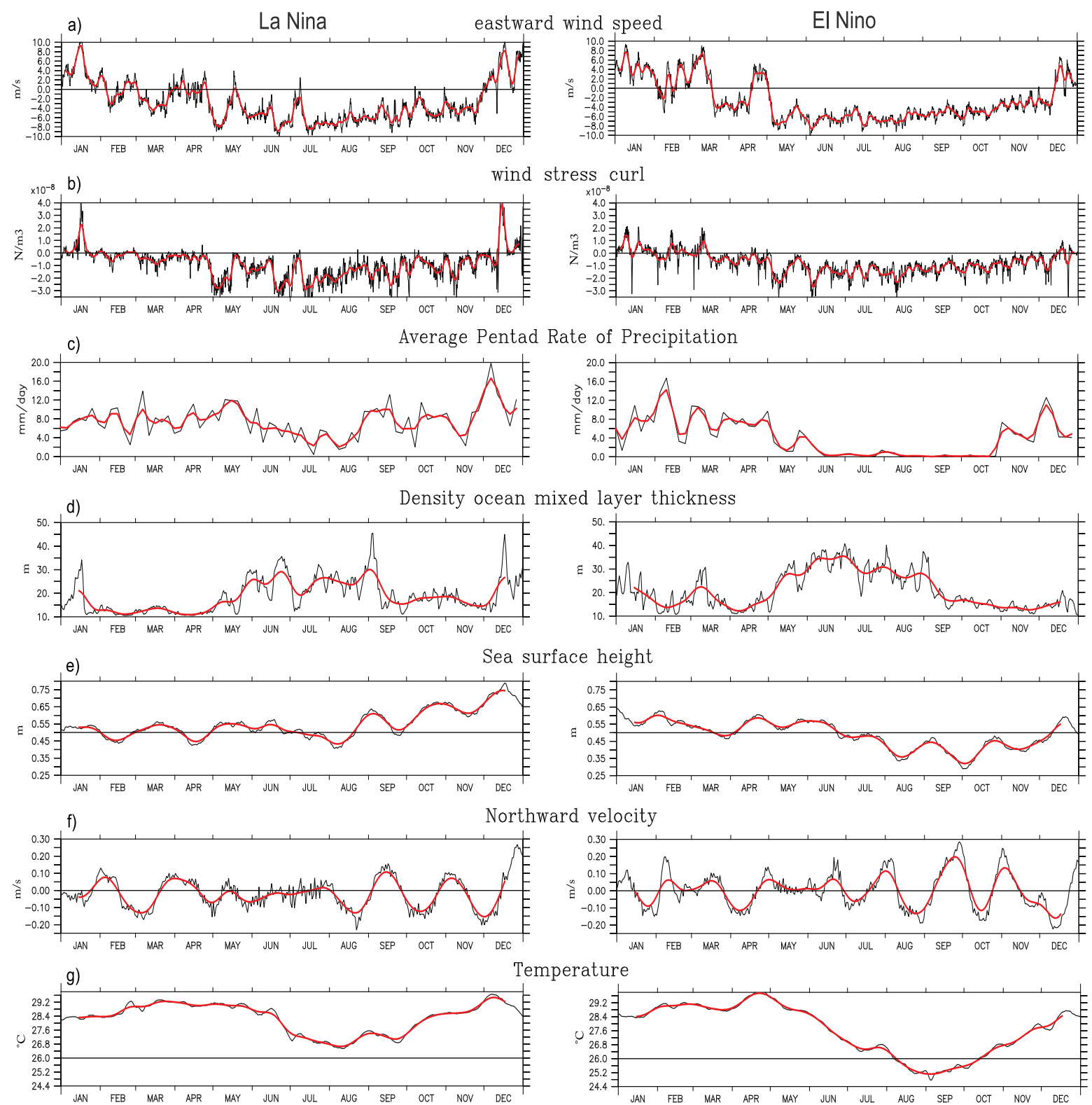

Temperature
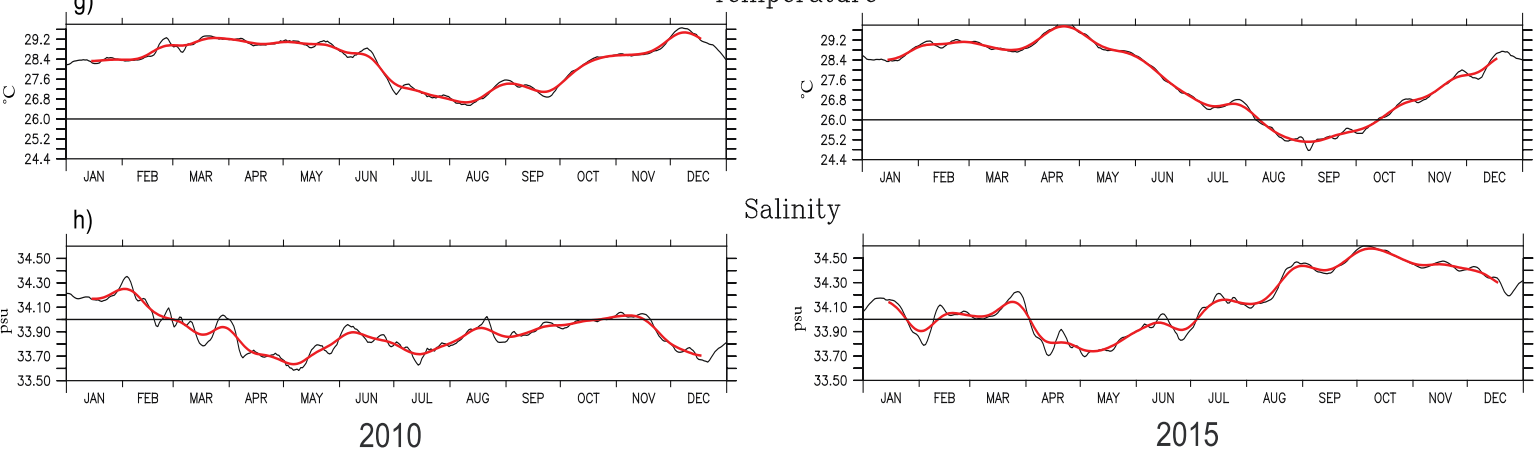
Salinity

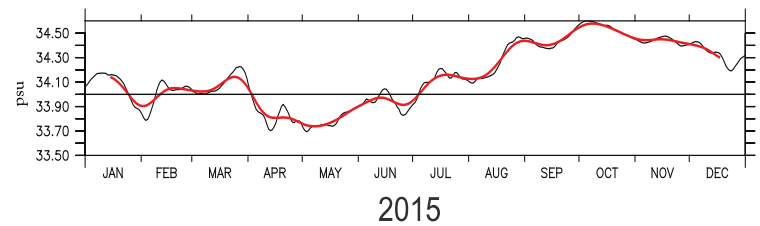

Figure 3. Time-series of surface ocean-atmosphere variables averaged over the study area $\left(109^{\circ} \mathrm{S}-111^{\circ} \mathrm{S} ; 8^{\circ} \mathrm{S}-12^{\circ} \mathrm{S}\right)$ in the Southern Java waters during the 2010 strong La Nina event (left panel) and the 2015 super El Nino event (right panel), for (a) zonal (eastward) wind speed, (b) wind stress curl, (c) precipitation rate, (d) density ocean mixed layer thickness, (e) sea surface height, (f) meridional (northward) current velocity, (g) seawater temperature, (h) salinity. Note that variables (f-h) are averaged from $50 \mathrm{~m}$ depth to the sea surface; red line is smoothed time-series with 7-day averaged. 
A classical theory of upper-layer ocean circulation suggested that the vertical component of the wind stress curl can be related to the mass transport, where the northward mass transport is equal to the positive wind stress curl that occurred during the NWM period (Figure 3b). In contrary, during the SEM from May to October it is revealed the negative wind stress curl, implying the southward mass transport in the upper layer. During the El Nino event the negative wind stress curl is much persistent and stable compared to that observed during the La Nina, where two spikes of the curl was observed at the beginning and at the end of the year.

Fluctuation of pentad mean of precipitation rate in Lan Nina and El Nino event over the study area revealed that precipitation rate was obviously much higher during the La Nina event than that during the El Nino (Figure 3c). Averaged precipitation in La Nina was about $7.534( \pm 3.487) \mathrm{mm} /$ day which was about double, compared to about $4.362( \pm 4.085) \mathrm{mm} /$ day in El Nino. Thus, the existence of very fresh water with salinity less than 34.20psu in the upper 50m depth in La Nina event (Figure 3h; and Figure 5a) was associated directly with high precipitation rate over the Maritime continent, including this study area.

Density-derived ocean mixed layer thickness during the SEM period is much deeper, compared to the NWM period (Figure 3d). However, it is clearly seen that the thickness is much deeper with maximum of $40 \mathrm{~m}$ depth during the El Nino event from May to September, compared to a high fluctuation of the thickness during the $\mathrm{La}$ Nina event. The mixed layer thickness is correlated with the magnitude of the wind stress or wind speed, as shown in Figure 3 ab.

Model sea surface height time-series during the SEM period in El Nino was much lower than that during the La Nina. If the value of $0.5 \mathrm{~m}$ is chosen as a reference, from July to November the sea surface height was below the reference in the El Nino. In contrary, in La Nina the sea surface height above the reference of $0.5 \mathrm{~m}$ (Figure $3 \mathrm{e}$ ). Variation of ocean current in the upper $50 \mathrm{~m}$ depth is dominated by an intraseasonal fluctuation which may be derived from throughflow eddies (Nof, 2002; Feng \& Wijffels, 2002) since the study area is closed to the outflow region of Indonesian Throughflow. However, amplitude of current fluctuation during the El Nino event was much stronger than that in the La Nina event (Figure 3f).

Fluctuation of seawater temperature and salinity showed a distinct pattern in the different ENSO events (Figure $3 \mathrm{~g}$-h). In the La Nina event, during the upwelling period it was found minimum temperature of $26.4^{\circ} \mathrm{C}$ and fresher salinity below 34.0psu. In contrary, much colder temperature of $25.5^{\circ} \mathrm{C}$ and much saltier salinity between 34.0$34.6 \mathrm{psu}$ were revealed during the upwelling period in the El Nino event.

\subsection{Contrast of Temperature, Salinity, and Current in the Upper $55 \mathrm{~m}$ Depth}

The depth-latitude of monthly averaged temperature, salinity, and meridional/zonal current component in the upper $55 \mathrm{~m}$ depth in the La Nina and the El Nino events were analyzed to investigate different vertical structure of these variables, as shown in Figure 4-6. The vertical distribution of temperature in La Nina event varied between 25.2 and $27.8^{\circ} \mathrm{C}$ (Figure $4 \mathrm{a}$ ). Much warmer water $\left(28.0^{\circ} \mathrm{C}\right)$ occurred in the coastal area north of $8.5^{\circ} \mathrm{S}$, while warm homogeneous water of $26.8-27.0^{\circ} \mathrm{C}$ was seen in the offshore area. High vertical gradient of temperature was also revealed near subsurface (below 40m depth) where high vertical stratifications of temperature between $25.2^{\circ} \mathrm{C}$ and $26.8^{\circ} \mathrm{C}$ were taken place, and the isotherm of $26.0^{\circ} \mathrm{C}$ remained below $45 \mathrm{~m}$ depth (Figure $4 \mathrm{a}$ ). If the isotherm of $26.0^{\circ} \mathrm{C}$ is referred as an indicator of upwelling it seems that during La Nina event 
upwelled water remained below sub-surface of $45 \mathrm{~m}$ depth and in the upper $45 \mathrm{~m}$ warmer water was dominant.

In the El Nino event, depth-latitude of temperature showed a presence of cooler sub-surface water that varied between 23.2$26.2^{\circ} \mathrm{C}$. Near the coastal area north of $9.5^{\circ} \mathrm{S}$ this cooler water below $45 \mathrm{~m}$ depth shallowed and outcropped near the coast. Isotherms of $25.0-26.2^{\circ} \mathrm{C}$ at $55 \mathrm{~m}$ depth is outcropped at the sea surface. High vertical gradient of temperature was found closed to the coastal area and below 45m depth (Figure 4b). In the offshore area, a homogeneous warmer water of $26.0-26.2^{\circ} \mathrm{C}$ was dominant.

By comparing these figures, it is revealed that La Nina event is associated with the present of warmer water with temperature $26.8-28.0^{\circ} \mathrm{C}$ in the upper $40 \mathrm{~m}$ depth. However, in El Nino event cooler temperature was dominant, as indicated by outcropping of isotherm $25.0-26.2^{\circ} \mathrm{C}$, highlighting much stronger upwelling intensity compared to previous La Nina event where the isotherms of $25.5-26.0^{\circ} \mathrm{C}$ remained below $45 \mathrm{~m}$ depth, while in El Nino event the isotherms outcropped at the sea surface and much cooler water was dominant below $40 \mathrm{~m}$ depth. It seems that in the La Nina event, upwelling process was suppressed by warmer water $\left(26.8-28.0^{\circ} \mathrm{C}\right)$ that covered in the upper $35 \mathrm{~m}$ depth.

Monthly sea surface temperature variation in the upwelling area decreases from June to August due to the strengthening of the Southeast Monsoon (SEM) winds (not shown). During La Nina event, the isotherms of $26-27^{\circ} \mathrm{C}$ was at a depth of $0-50 \mathrm{~m}$, whereas in the El Nino event there was surfacing isotherms of $25-26^{\circ} \mathrm{C}$ near the coastal area and deepening isotherm of $26^{\circ} \mathrm{C}$ from sea surface to a depth of about $50 \mathrm{~m}$ in offshore area (Figure 4b). This indication shows the change of isotherm from $26^{\circ} \mathrm{C}$ to $25^{\circ} \mathrm{C}$. The obvious difference between La Nina and El Nino events was that temperature above $26.8^{\circ} \mathrm{C}$ in $\mathrm{La}$ Nina event has spread out entirely from the study area. However, in El
Nino event there was still a shift from the $26^{\circ} \mathrm{C}$ to the $24^{\circ} \mathrm{C}$ isotherms.

Figure $4 \mathrm{~b}$ showed that upwelling during the super El Nino event is clearly indicated by a surface outcrop of isotherms of $25^{\circ} \mathrm{C}$ and $26^{\circ} \mathrm{C}$ from latitude of $9.75^{\circ} \mathrm{S}$ to the south, and existence of surface colder water between $23.2^{\circ} \mathrm{C}$ and $25.5^{\circ} \mathrm{C}$ from latitude of $9.75^{\circ} \mathrm{S}$ to the north. Furthermore, it is revealed much stronger meridional gradient of isotherms between offshore and coastal region. Here, region of colder upwelling extended from the shore to about $195 \mathrm{~km}$ toward offshore.

The temperature drop that occurred in El Nino event showed that the upwelling process that occurred at this time was still towards the peak time of upwelling. Shallowing the isotherms slope from offshore towards the coastal was considered to be occurred as a response of upper ocean Ekman transport toward offshore forced by the SEM winds fields and this indicated a strong upwelling, in good agreement with Purba (2007).

The temperature difference near the coastal upwelling region that occurred in $\mathrm{La}$ Nina and El Nino events was about $2^{\circ} \mathrm{C}$, which was much colder upwelling in El Nino event. Ningsih et al. (2013) reported that the SST in the Southern Java waters during the SEM period ranged from $23.6^{\circ} \mathrm{C}-28.0^{\circ} \mathrm{C}$. Arisandi et al. (2017) suggested that reduced rainfall and cloud coverage during El Nino event will increase the intensity of sunlight absorption and the deeper depth of the thermocline layer.

The depth-latitude of monthly averaged salinity in La Nina event ranged between 33.48-34.4psu (Figure 5a). Distribution of salinity in the upper-layer (0$55 \mathrm{~m}$ depth) showed the occurrence of a very freshwater with salinity less than 33.80psu.

Near the coastal area, a relatively high horizontal salinity gradient was found between isohaline of 33.68-34.16psu. However, a relatively salty water ( $>34.2 \mathrm{psu}$ ) remained below $25 \mathrm{~m}$ depth. A core layer of 
very fresh water $(<33.60 \mathrm{psu})$ was revealed near $9^{\circ} \mathrm{S}$ in the upper $20 \mathrm{~m}$ depth (Figure 5a), corroborated a high precipitation rate over the study area (Figure 3c).

In the El Nino event, salinity varied between 34.16-34.72psu, which as much saltier than that in La Nina (Figure 5b). Outcropped of isohalines of 34.20-34.44psu were found from below $45 \mathrm{~m}$ depth to the sea surface. North of latitude of $9^{\circ} \mathrm{S}$ outcropped of isohalines 34.24-34.44 was dominant. This uplifted isohalines from the sub-surface to the sea surface may be associated with upwelling processes, which was consistent with uplifted cooler water from sub-surface (Figure 4b). Thus, the model salinity and seawater temperature in the southern Java waters can be used as a proxy of upwelling.

Steward (2008) suggested that the mixing of water masses due to the presence of winds, currents, tides, and freshwater input from streams or rains affects

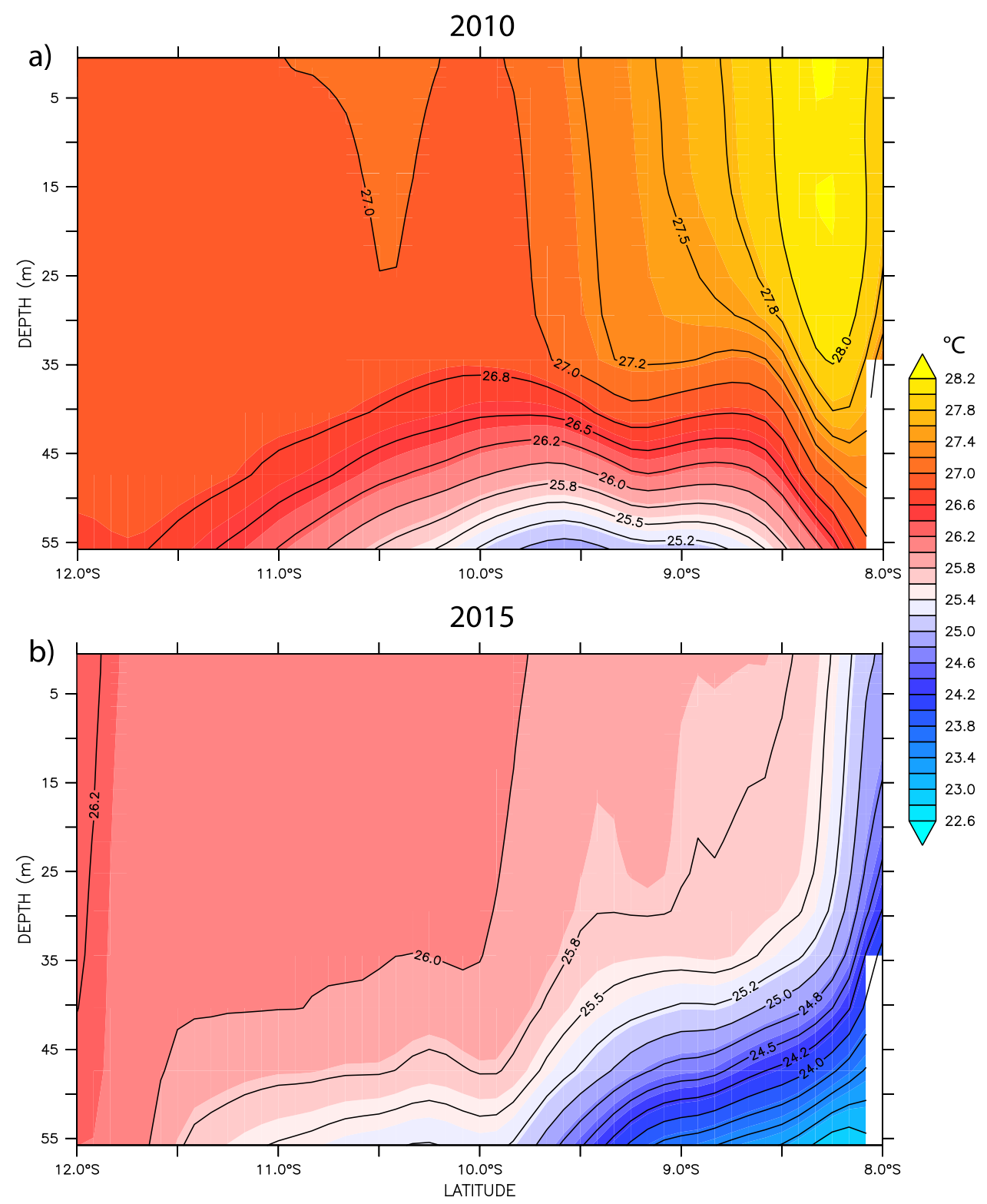

Figure 4. Depth-latitude section (A-B) of monthly averaged temperature in the upper $55 \mathrm{~m}$ depth in August 2010 (a) during La Nina, and August 2015 (b) El Nino events, respectively. 
surface salinity variation. Atmadipoera et al. (2009) documented that the increase in salinity of the waters in the Southern Java occurred from August to the peak in September reaching 34.3psu.

The surface salinity in La Nina event ranged from 33.48-34.48psu, but in El Nino event surface salinity ranged from 34.1634.72psu. Getting closer to the coast shows an increase in salinity as an indicator of coastal upwelling. This is due to the upwelling process which raises the mass of water from the lower layer with high salinity to the surface.
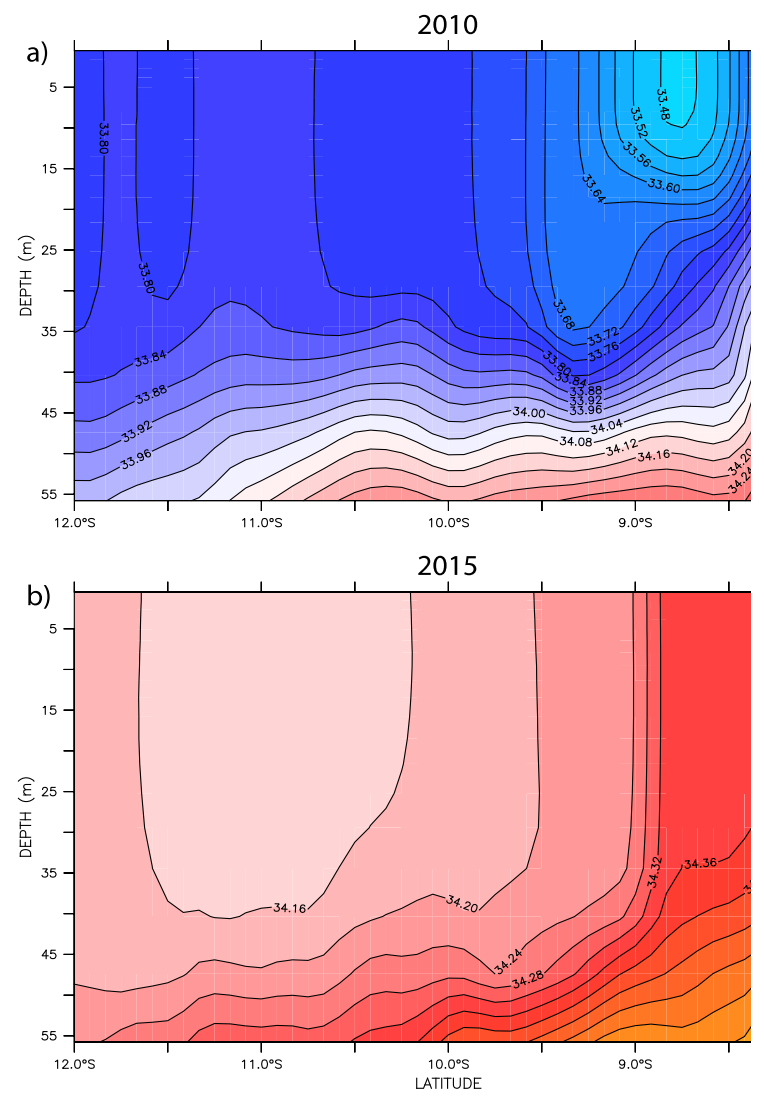

Figure 5. Depth-latitude section (A-B) of monthly averaged salinity in the upper 55m depth in August 2010 (a) and August 2015 (b) during La Nina and El Nino events, respectively.

Wardani et al. (2014) showed that La Nina associated with monsoon winds affected the mean salinity at a depth of 0 $300 \mathrm{~m}$. In the La-Nina period, the movement of warm pools towards the central equator Pacific which was followed by greater evaporation led to higher rainfall frequencies and lower salinity than normal phases, as shown from the pentad precipitation rate in Figure 3c.

Depth-latitude section of meridional and zonal current component in the upper $55 \mathrm{~m}$ depth in La Nina and El Nino events are presented in Figure 6-7. Negative (positive) meridional current component indicates the flow southward (northward), but for the zonal current component is westward (eastward), respectively. In the La Nina event the southward flow of meridional current component was found from latitude of $9.75^{\circ} \mathrm{S}$ to the south (offshore) with maximum speed of $-0.2 \mathrm{~m} / \mathrm{s}$ (Figure 6a). The second core of weak southward flow was closed to the coastal region $\left(8-9^{\circ} \mathrm{S}\right)$ in the upper $35 \mathrm{~m}$ depth. A weak northward flow of about $+0.03 \mathrm{~m} / \mathrm{s}$ was also revealed at latitude of 9 $9.5^{\circ} \mathrm{S}$ below $40 \mathrm{~m}$ depth.

The zonal current component revealed remarkable westward flows in the offshore area and eastward flows near the coastal area with the current boundary near latitude of $9.25^{\circ} \mathrm{S}$ (Figure 6b). Near latitude of $9.5^{\circ} \mathrm{S}$ to the south (offshore) a strong westward flow was found with maximum zonal amplitude of about $>0.44 \mathrm{~m} / \mathrm{s}$. A boundary current of westward and eastward flows was situated between latitude of 9.0$9.5^{\circ} \mathrm{S}$ indicated with zero isoline. High horizontal stratification of the westward flow appeared between $9.25-10.25^{\circ} \mathrm{S}$.

Furthermore, in the latitude of $9.25^{\circ} \mathrm{S}$ to the north, a strong persistent eastward flow was observed with core layer of maximum current between $0.30-0.44 \mathrm{~m} / \mathrm{s}$ near latitude of 8.0-8.5 ${ }^{\circ} \mathrm{S}$ from sea surface down to about $55 \mathrm{~m}$ depth (Figure 6b). Previous studies have well documented that this strong surface eastward flow is characteristics of the upper layer of the South Java Coastal Current (SJCC) which has large variability from 


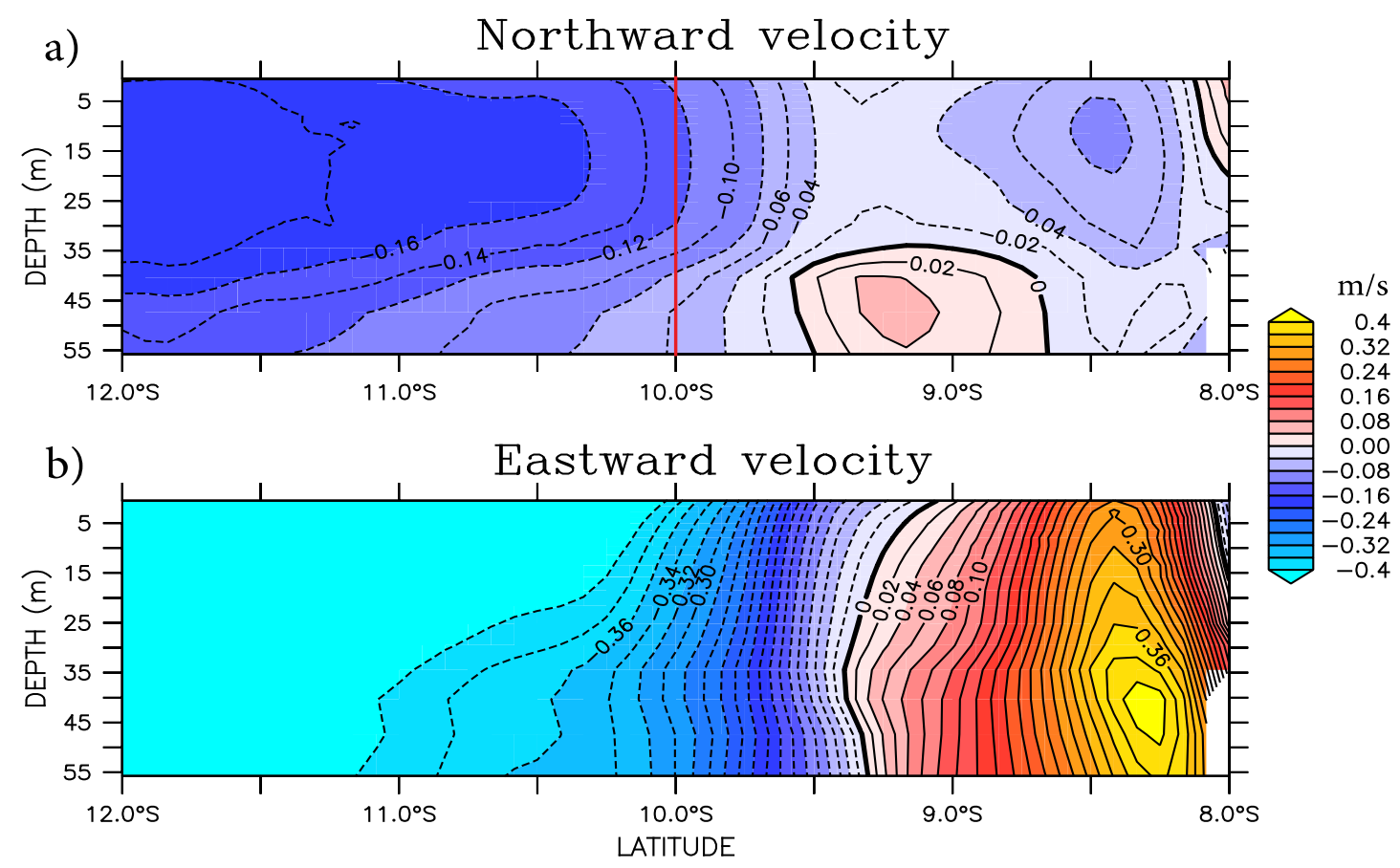

Figure 6. Depth-latitude section (A-B) of (a) monthly averaged meridional current and (b) zonal current components in the upper 55m depth in August 2010 during La Nina event. A vertical red line in the latitude of $10^{\circ} \mathrm{S}$ denotes for transport volume calculation in August only (discussed in section 3.2).

intraseasonal to semiannual scales (Quadfasel \& Cresswell, 1992; Sprintall et al., 1999; Sprintall et al., 2010; Utari et al., 2019).

It is revealed that in La Nina event the eastward SJCC was dominant north of $9.25^{\circ} \mathrm{S}$, meanwhile, south of latitude of $9.5^{\circ} \mathrm{S}$ the resultant current flowed between westward and southwestward. In this $\mathrm{La}$ Nina event the southward flow may be associated partly with the Ekman transport of mass as a response to local easterly monsoon winds, particularly in the latitude of $10^{\circ} \mathrm{S}$ to the south. Others forcing may be contributed to this flow, such as large-scale circulation and inter-ocean circulation of Indonesian Throughflow.

This current separation with eastward flow near the coast and westwardsouthwestward flow in the offshore area (near latitude of $9.5^{\circ} \mathrm{S}$ to the south) demonstrated complex circulation dynamics in this region, as not as simple, if we applied only the Ekman transport calculation derived from surface meridional wind-stress to estimate upwelling's Ekman transport of mass. Here, local circulation was modulated by a large-scale inter-basin circulation and also remotely forced current from equatorial Indian Ocean, such as the Indonesian Throughflow and SJCC (Sprintall et al., 1999; 2010).

In El Nino event meridional current component showed southward flow in the latitude of $9.5^{\circ} \mathrm{S}$ to the south with maximum amplitude of $0.14 \mathrm{~m} / \mathrm{s}$, while to the north weak northward (positive) flow with maximum of velocity of $0.08 \mathrm{~m} / \mathrm{s}$ (Figure 7a). On contrary, zonal current component revealed a strong persistent westward (negative) flow with maximum amplitude of above $0.40 \mathrm{~m} / \mathrm{s}$ almost in the entire section (Figure 7b). Small part of strong eastward flow was noted north of $8.5^{\circ} \mathrm{S}$ below $30 \mathrm{~m}$ depth, which may be associated with the SJCC that varied spatially during this El 


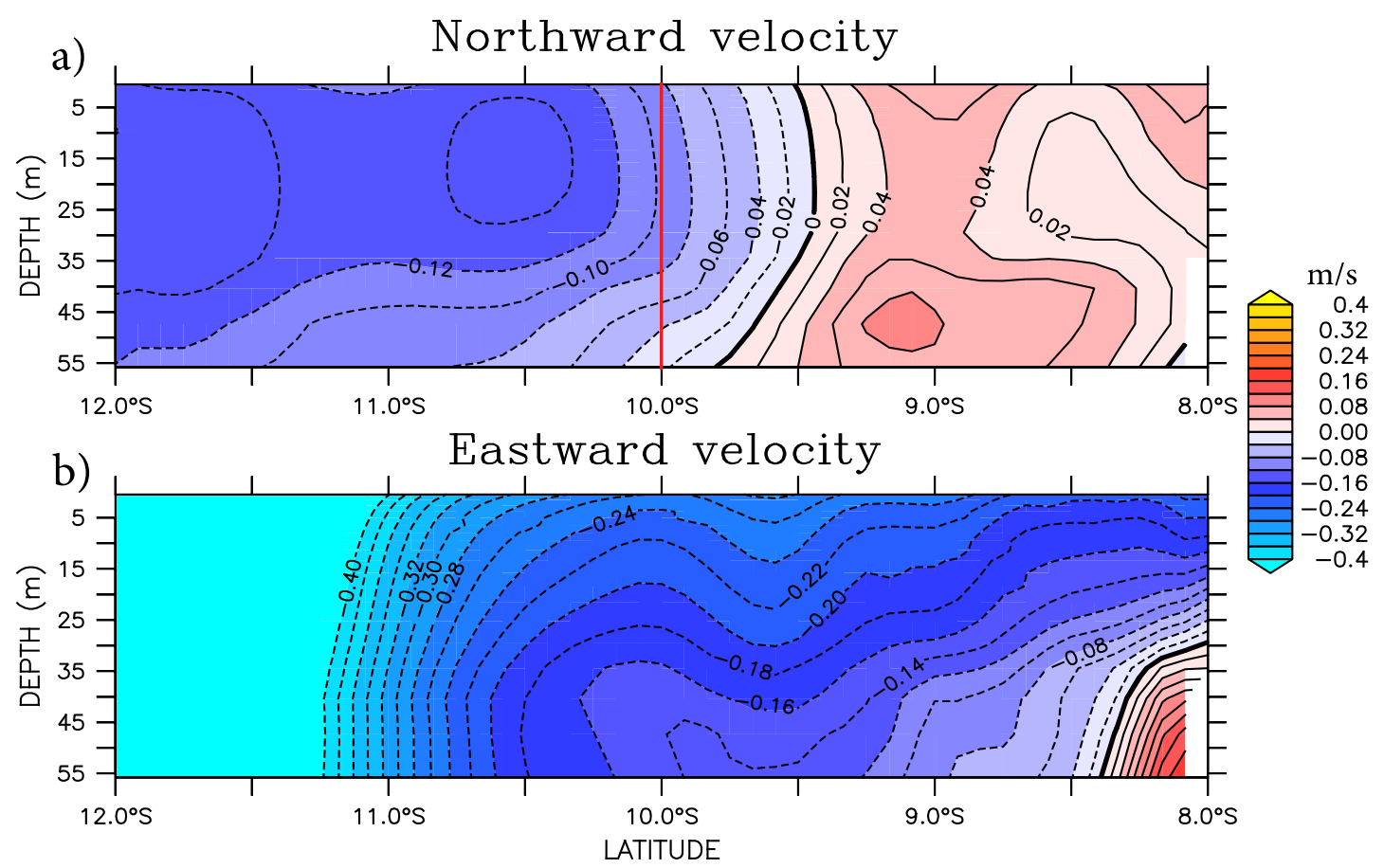

Figure 7. Depth-latitude section (A-B) of (a) monthly averaged meridional current and (b) zonal current components in the upper 55m depth in August 2015 during El Nino event. A vertical red line in the latitude of $10^{\circ} \mathrm{S}$ denotes for transport volume calculation in August only (discussed in section 3.2).

Nino event. In the El Nino event, a relatively strong southward flow from latitude of $9.5^{\circ} \mathrm{S}$ to the south was prominent with magnitude of velocity above $0.15 \mathrm{~m} / \mathrm{s}$ (Figure $7 \mathrm{a}$ ). This flow pattern was similar to those observed during La Nina (Figure 6a). However, in the latitude of $9.5^{\circ} \mathrm{S}$ to the north, the flow was northward toward the coastal region with a weak velocity of about $0.03-0.07 \mathrm{~m} / \mathrm{s}$.

The resultant current can be estimated from these current components, where the westward-southwestward flows appeared in the latitude of $9.75^{\circ} \mathrm{S}$ to the south, and westward-northwestward flows north of $9.75^{\circ} \mathrm{S}$ (Figure 7). Again, a complex surface circulation in the upper $50 \mathrm{~m}$ depth was found during this El Nino year, as similar to those described during La Nina year. This means that large-scale circulation intervened significantly to the local circulation forced by the local wind stress field. This means in the El Nino event the strong westward flow (zonal current component) in the upper layer agreed with the southward flow (meridional component) that resulted the circulation flowing westward-southwestward which favored the mass transport away from the coastal area. Lagrangian analysis of water mass from the coastal area during El Nino event in August 2015 indicated that the trajectory paths of water mass flow directed southwestward (not shown).

It is clearly seen that in La Nina event, in the upper $55 \mathrm{~m}$ depth, meridional current component is dominant flowing southward (to the offshore area), and weak northward flow $(<0.03 \mathrm{~m} / \mathrm{s})$ below $35 \mathrm{~m}$ depth in the latitude of $9^{\circ} \mathrm{S}$ (Figure 6). Similarly, during the 2015 El Nino event, the strong southward flow was dominant in the upper $50 \mathrm{~m}$ depth from $9.5^{\circ} \mathrm{S}$ to the south, and weak northward flow $(0.03-0.07 \mathrm{~m} / \mathrm{s})$ from latitude of $9.5^{\circ} \mathrm{S}$ to the coastal area.

The strong southward flow during both ENSO event may be related to the upper-layer Ekman transport forced by the 


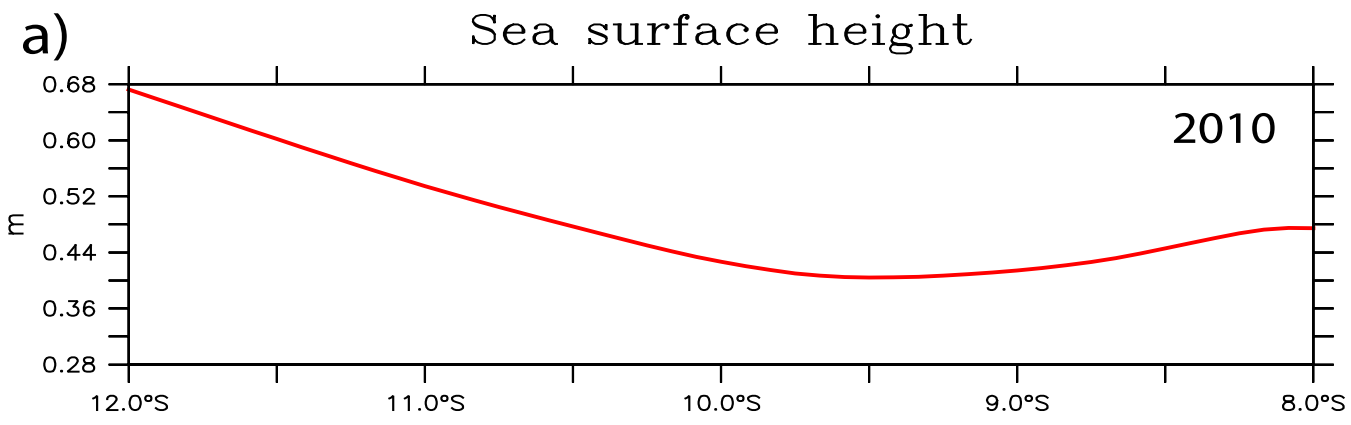

b)

LATITUDE

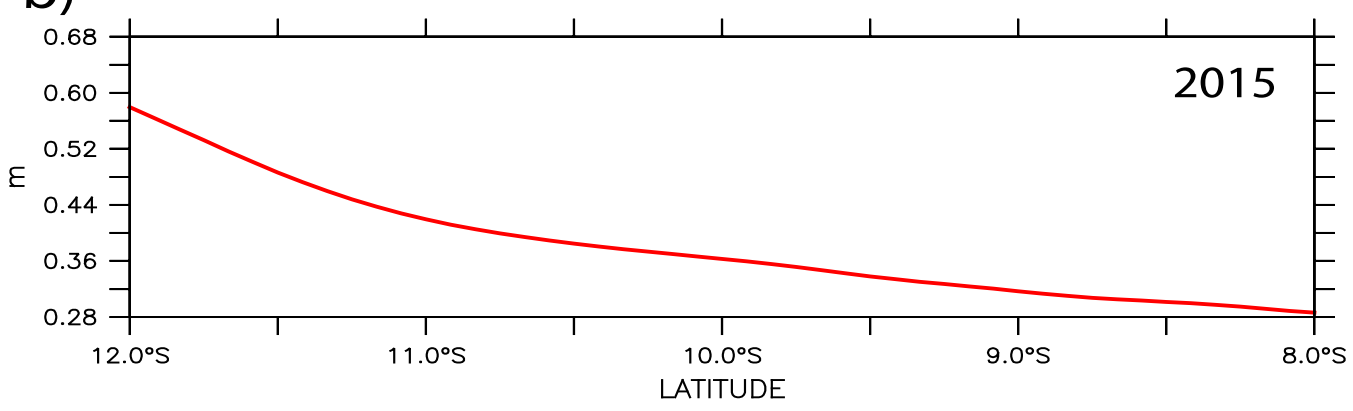

Figure 8. Monthly averaged sea surface height along the section C-D in August, (a) in the 2010 La Nina, and (b) in the 2015 El Nino events.

easterly monsoon winds (section 3.3 will discuss the wind stress curl related to this Ekman transport). There was a boundary of meridional current near latitude of $9.5^{\circ} \mathrm{S}$ separating the strong southward flow and weak northward flow were found (Figure 7). It is speculated that the positive meridional current north of latitude $9.5^{\circ} \mathrm{S}$ may be associated with the existence of eastward SJCC. During the El Nino event, upwelling developed by Indonesian Throughflow (ITF) brought cold water masses with shallow thermocline depths and the strengthening of the SEM winds (Pranowo et al., 2005). Kuswardani \& Qiao (2014) reported the ITF contributed to the formation of upwelling in the Southern Java waters which by increasing in vertical velocity towards the surface from the depth of $80 \mathrm{~m}$.

Model sea surface height during La Nina event exhibited a high sea surface height $(0.68 \mathrm{~m})$ in the latitude of $12^{\circ} \mathrm{S}$ (offshore) and then the slope descended to the north until the latitude of $9.5^{\circ} \mathrm{S}$ (about $0.4 \mathrm{~m})$. From here to the coastal area $\left(8^{\circ} \mathrm{S}\right)$ sea surface height increased again moderately up to $0.48 \mathrm{~m}$ (Figure 8a). The difference of sea surface height in the coastal area $\left(8^{\circ} \mathrm{S}\right)$ and offshore $\left(12^{\circ} \mathrm{S}\right)$ was about $0.2 \mathrm{~m}$. Turning point of sea surface height at latitude of $9.75^{\circ} \mathrm{S}$ corroborated the current separation (boundary) in Figure 6.

During El Nino event sea surface height was maximum $(0.56 \mathrm{~m})$ in the offshore area $\left(12^{\circ} \mathrm{S}\right)$, and decreased continuously to the coastal area at latitude of $8^{\circ} \mathrm{S}$ and reached $0.28 \mathrm{~m}$. The difference of sea surface height is about $0.28 \mathrm{~m}$ that was much higher than that found in the 2010 La Nina event (Figure 8a).

\subsection{Contrast of Transport Volume and Temperature-based Upwelling Index}

Time series of transport volume in the upper $50 \mathrm{~m}$ depth along a section C-D (along latitude of $10^{\circ} \mathrm{S}$ ) during different ENSO period is shown in Figure 9. In the La Nina event the mean transport volume is about $0.062( \pm 0.905) \mathrm{Sv}$ (toward offshore). Large variation of the transport occurred during the 

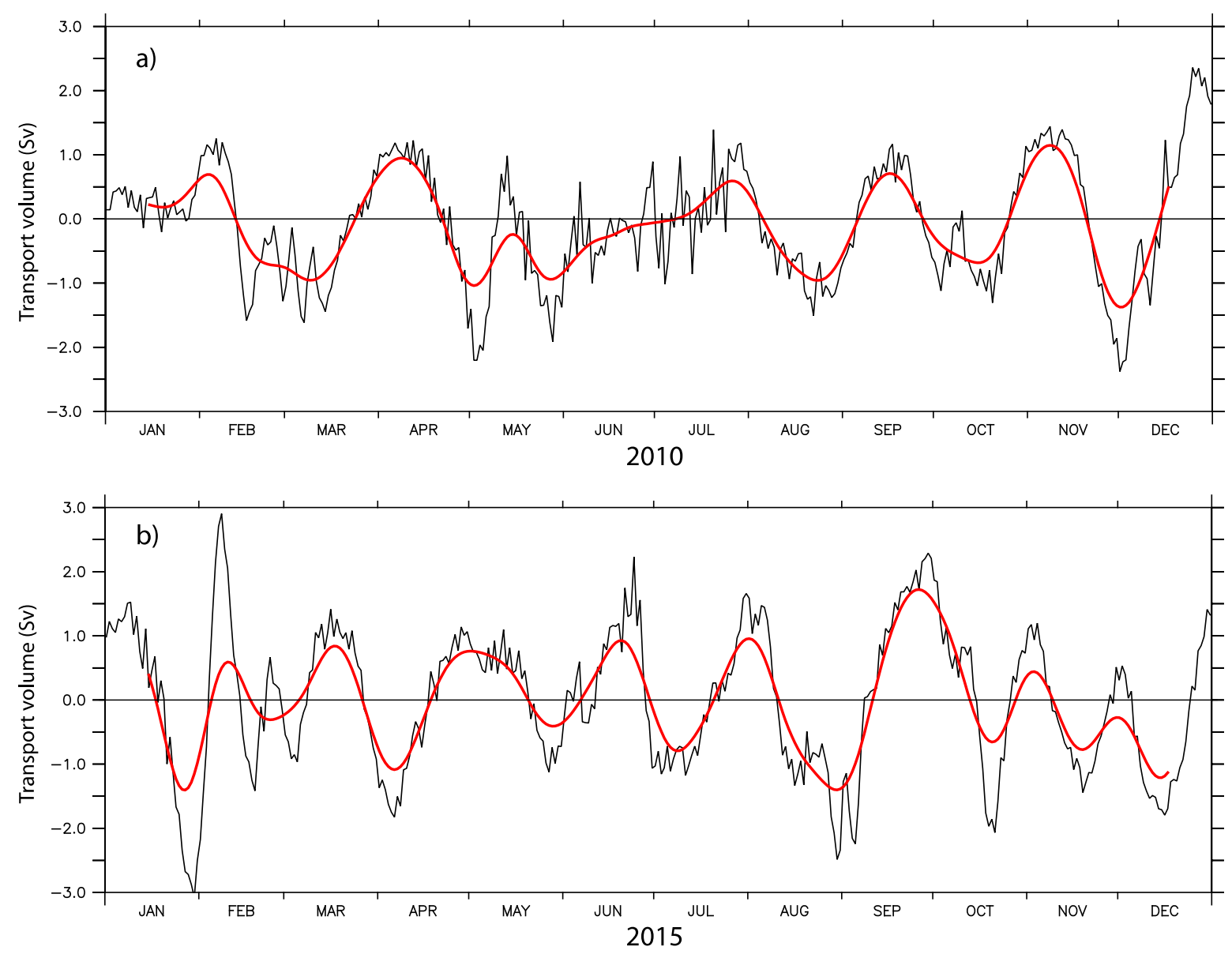

Figure 9. Time-series of transport volume in the upper 50m depth in a section C-D (latitude $10^{\circ} \mathrm{S}$ ), during the $2010 \mathrm{La}$ Nina event (a) and the $2015 \mathrm{El}$ Nino event (b). Negative (positive) value denotes the transport direction toward offshore (onshore), respectively.

NWM period, but a weak fluctuation was seen during the SEM 'upwelling' period from May to October with transport values closed to zero during peak of the SEM in August-September (Figure 9a). Large contribution to the negative transport (toward offshore) was derived from the transport between March-April and November with amplitude of about $-1.5 \mathrm{~Sv}$, which appeared during the NWM period. Transport volume estimate in August, as calculated from a section at latitude $10^{\circ} \mathrm{S}$ (see vertical red line in Figure 6a), revealed a transport volume toward offshore about $-0.648 \pm 0.516 \mathrm{~Sv}$, which is consistent with strong negative meridional current component in Figure 6a.
In the El Nino event mean transport volume is very weak toward onshore, but very high standard deviation at +0.0003 $( \pm 1.107) \mathrm{Sv}$ (toward onshore). During the SEM 'upwelling' period between MayOctober, the fluctuation of positive transport was clearly seen with its amplitude of +1.5 $\mathrm{Sv}$ in September-October (Figure 9b). This result is surprisingly not expected since the transport volume was reversed toward onshore (downwelling-like) during the upwelling period from May to October. Negative transport only appeared in January, February and April with large fluctuation at amplitude of about 2 Sv. However, if transport volume is calculated only in August 
across latitude of $10^{\circ} \mathrm{S}$ (as shown in Figure $7 \mathrm{a}$, vertical red line), it is found about -0.446 $\pm 1.156 \mathrm{~Sv}$ toward offshore.

At present it is difficult to explain this unexpected result. However, it is assured that numerical calculation of the 3dimensions meridional current component from the INDESO model output has considered not only local atmospheric fluxes and surface wind stress, but also other important forcing such as explicit tidal forcing, density of seawater, pressure gradient force, Coriolis force. Furthermore, large-scale regional circulation of Indonesian Throughflow and remotely forced equatorial current from the Indian Ocean, such as eastward SJCC influence significantly on the local dynamics in the study area, and have been considered in the INDESO model (Tranchant et al., 2015; Sprintall et al., 2010). As shown in Figure 6 and 7, in previous section, the strong eastward SJCC was persistent during La Nina, separating strong westward flow from $9.5^{\circ} \mathrm{S}$ to the south, as part of upper component of ITF.

In addition, during El Nino event, the SJCC deepened below sub-surface but strong westward flow was visible (Figure 7). Further study with diagnostic analysis for each forcing should be done in the next study to examine a contribution of each forcing to the resultant of the current component.

In the classical theory of the coastal upwelling, Ekman transport is only
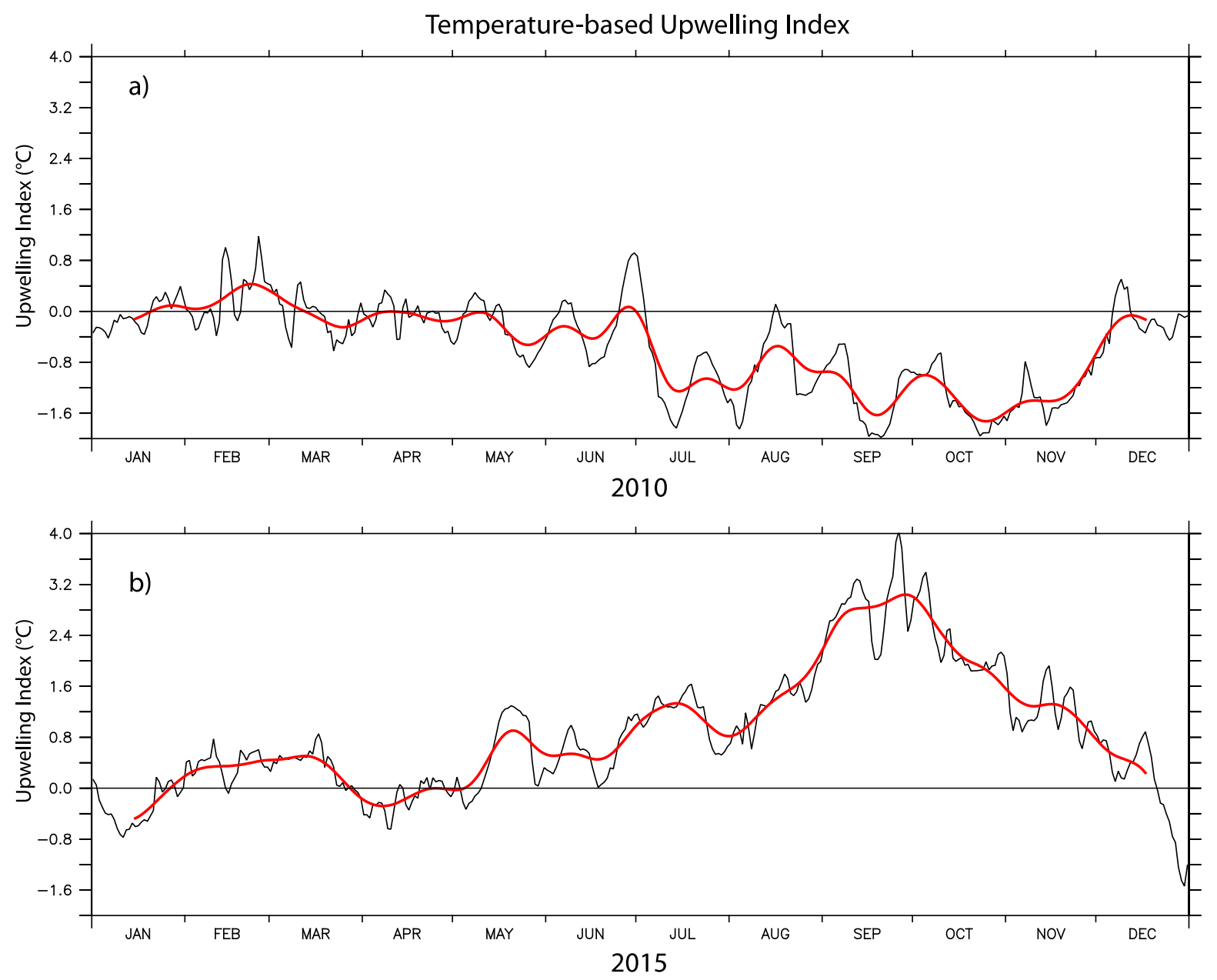

Figure 10. Time-series of 120-day smoothed temperature-based upwelling index data during the 2010 La Nina event (blue) and the 2015 El Nino event (red). 
Table 1. Contrast of upwelling characteristics (August) during different ENSO events.

\begin{tabular}{lcc}
\hline Ocean-atmosphere variable & La Nina $(2010)$ & El Nino $(2015)$ \\
\hline Zonal wind speed $(\mathrm{m} / \mathrm{s})$ & $-6.41 \pm 1.269$ & $-5.86 \pm 1.084$ \\
Wind stress curl $\left(\mathrm{N} / \mathrm{m}^{3}\right)$ & $-1.521 \mathrm{E}-8 \pm 6.7 \mathrm{E}-9$ & $-1.375 \mathrm{E}-8 \pm 5.1 \mathrm{E}-9$ \\
Meridional current $(\mathrm{m} / \mathrm{s})$ & $-0.092 \pm 0.063$ & $-0.046 \pm 0.130$ \\
Meridional transport $(\mathrm{Sv})$ & $0.0577 \pm 0.44$ & $0.2866 \pm 0.55$ \\
Mixed layer thickness $(\mathrm{m})$ & $24.90 \pm 3.6$ & $27.84 \pm 4.9$ \\
Sea surface height $(\mathrm{m})$ & $0.4858 \pm 0.069$ & $0.3818 \pm 0.032$ \\
Sea surface temperature $\left({ }^{\circ} \mathrm{C}\right)$ & $26.90 \pm 0.33$ & $25.63 \pm 0.42$ \\
Temp.-based upwelling index $\left({ }^{\circ} \mathrm{c}\right)$ & 0.84 & 3.17 \\
& & outcropped at sea \\
Depth of $26^{\circ} \mathrm{C}$ isotherm $(\mathrm{m})$ & 50 & surface \\
Salinity in the upper $55 \mathrm{~m}(\mathrm{psu})$ & $33.88 \pm 0.07$ & $34.26 \pm 0.14$ \\
\hline
\end{tabular}

calculated from the surface wind stress, which may yield a prominent result of the transport toward offshore (onshore) for the reversal seasonal surface meridional wind stress is easterly (westerly) over the study area (discussion on the wind stress curl is in next section 3.3). As shown in equation (2) in the Research Methods, the temperaturebased upwelling index (TUI) is defined as a difference of sea surface temperature in the offshore location $\mathrm{B}$ and in the onshore location A (Figure 1). This method was adopted from Benazzouz et al. (2014). The amplitude of the TUI is evaluated during the upwelling period between May and October for each ENSO year (La Nina and El Nino). During this period, negative TUI means that temperature at location A (onshore) is much warmer than the SST at location B (offshore), and vice versa, for positive TUI. It is clearly seen a contrast of TUI series in La Nina and El Nino events (Figure 10). In the SEM 'upwelling' period between May and October the contrast of TUI is seen clearly.

In the La Nina event, the negative TUI commenced from May to December with the minimum of TUI was reached in September-October at about $-2.0^{\circ} \mathrm{C}$ (Figure 10a). The TUI series showed a strong intraseasonal fluctuation with amplitude of $0.5-1^{\circ} \mathrm{C}$. In contrast, in the El Nino event, the positive TUI was found during the SEM 'upwelling' period from May to November with its maximum was between September and October at about $+4.0^{\circ} \mathrm{C}$ (Figure 10a).

Figure 10 showed that seasonal Ekman upwelling was modulated by the ENSO event, indicating the intensity of upwelling increased drastically during the El Nino event. In good agreement with Santos et al. (2005), suggesting that a high upwelling index indicates a strong upwelling event and a low index indicates a weak upwelling event. So that the El Nino event has a significant impact on upwelling intensity, compared to the La Nina event.

Characteristics of upwelling in the Southern Java waters during different ENSO event is summarized in Table 1. The upwelling feature in the 2010 La Nina event was indicated by warmer and fresher water in the upper layer and temperature-based upwelling index was relatively low (about $0.84^{\circ} \mathrm{C}$ ), the isotherm of $26^{\circ} \mathrm{C}$ remained at 50 $\mathrm{m}$ depth, and high sea surface height (above $0.5 \mathrm{~m})$. On contrary, in the $2015 \mathrm{El}$ Nino event, upwelling intensity showed a high upwelling index of $3.17^{\circ} \mathrm{C}$, an outcropped isotherm of $25-26^{\circ} \mathrm{C}$ at the sea surface, very low (below $0.5 \mathrm{~m}$ ) sea surface height. In addition, upper-layer. Small difference of variables was found for meridional winddriven upper-layer circulation inferred from wind stress curl, which may be related to the influence of westward flow of the Indonesian 
throughflow, where its transport volume is enhanced during the La Nina and decreased during El Nino year (Gordon et al., 2019).

\section{CONCLUSION}

Characteristics of seasonal upwelling during different ENSO events in the Southern Java waters have been investigated, particularly in the 2010 strong La Nina and the 2015 super El Nino years, by using the validated datasets from a $1 / 12^{\circ}$ ocean general circulation model output of INDESO and complemented by the satellite-derived surface wind fields and precipitation rate. It is found that seasonal upwelling during different ENSO events can be described clearly from several surface oceanatmosphere variables. In the La Nina event negative meridional wind speed and wind stress curl, mixed layer thickness, and upper surface salinity were much lower, but, precipitation rate, sea surface temperature, and sea surface height were much higher compared to those occurred in the El Nino event. Furthermore, vertical structure of seawater temperature and salinity in the upper $55 \mathrm{~m}$ depth revealed that in La Nina event cooler upwelled water were concealed since colder upwelled water $<26^{\circ} \mathrm{C}$ remained below $45 \mathrm{~m}$ depth and a very freshwater with salinity $<33.80$ psu was dominant.

On contrary, in the El Nino event isotherm of $25^{\circ} \mathrm{C}$ and $26^{\circ} \mathrm{C}$ were outcropped from $55 \mathrm{~m}$ depth to the sea surface and much cooler water $\left(<25.5^{\circ} \mathrm{C}\right)$ was dominant north of latitude of $9^{\circ} \mathrm{S}$. Isohalines of 34.24$34.44 \mathrm{psu}$ were also outcropped at the sea surface. A difference of surface temperature and salinity during different ENSO events were about $2^{\circ} \mathrm{C}$ and $0.84 \mathrm{psu}$ respectively. The contrast of temperature-based upwelling index in La Nina and El Nino events was obviously seen at about $-2^{\circ} \mathrm{C}$ and $+4^{\circ} \mathrm{C}$, respectively, indicating the ENSO events have strongly modulated the intensity of seasonal upwelling in the study area.
Estimate of Ekman transport volume derived from model output datasets was intervened by large-scale circulation in the region such as the SJCC and the ITF. In La Nina event, ocean current in the upper $55 \mathrm{~m}$ depth exhibited a strong eastward SJCC in the coastal area, but it diminished in El Nino event. Furthermore, strong westwardsouthwestward flows in the offshore region were persistent both in different ENSO events. The current boundary was situated at latitude of $9.5^{\circ} \mathrm{S}$. Thus, in the next study, diagnostics analysis of the model is needed to evaluate the magnitude of each forcing in the model, and to estimate Ekman transport of mass away from the coastal region.

\section{ACKNOWLEDGMENTS}

We would like to thank INDESO project Indonesia and INDESO project office in CLS and MERCATOR-OCEAN Toulouse France for providing and accessing to the model output datasets. The surface atmosphere datasets are available at https://apps.ecmwf.int/datasets/data. The precipitation data are available from https://psl.noaa.gov/data/gridded/data.cmap.h tml. We wish to thank two Reviewers for suggestion and critics to improve the manuscript.

\section{REFERENCES}

Arisandi, C.A., M.I. Jumarang, and Apriansyah. 2017. Variabilitas suhu dan salinitas perairan selatan Jawa Timur. Prisma Fisika, 5(3): 131-137.

Atmadipoera, A.S. \& P. Widiyastuti. 2014. A numerical modeling study on upwelling mechanism in the Southern Makassar Strait. J. Ilmu dan Teknologi Kelautan Tropis, 6(2): 355371.

https://doi.org/10.29244/jitkt.v6i2.901 2

Atmadipoera, A.S. \& P. Hasanah. 2017. Karakteristik dan variabilitas 
ARLINDO Flores dan Koherensinya dengan Arus Pantai Selatan Jawa. J. Ilmu dan Teknologi Kelautan Tropis, 9(2): 537-556.

https://doi.org/10.29244/jitkt.v9i2.192 89

Atmadipoera A.S., R. Molcard, G. Madec, S. Wijffels, J. Sprintall, A. KochLarrouy, I. Jaya, \& A. Supangat. 2009. Characteristics and variability of the Indonesian throughflow water at the outflow straits. Deep-Sea Research I, 56(1): 1942-2954.

http://pordlabs.ucsd.edu/jsprintall/pub _dir/atmadipoera2009.pdf

Benazzouz, A., S. Mordane, A. Orbi, M. Chagdali, K. Hilmi, A. Atillah, J.L. Pelegri, \& H. Demarcq. 2014. An improved coastal upwelling index from sea surface temperature using satellite-based approach- the case of the canary current upwelling system. J. Continental Shelf Research, 81(1): 38-54.

https://doi.org/10.1016/j.csr.2014.03. 012

Feng, M. \& S. Wijffels. 2002. Intraseasonal variability in the SEC of the East Indian ocean. J. Phys. Oceanogr., 32: 265-277.

https://doi.org/10.1175/15200485(2002)032\%3C0265:IVITSE\%3 E2.0.CO;2

Gaol, J.L., K. Mahapatra, Y. Okada, B.P. Pasaribu, D. Manurung, \& I.W. Nurjaya. 2002. Fish catch relative to environmental parameters observed from satellite during ENSO and dipole mode events 1997/98 in South Java Sea. Proceedings of PORSEC, 411-417 pp.

Gordon, A.L., A. Napitu, B.A. Huber, L.K. Gruenburg, K. Pujiana, T. Agustiadi, A. Kuswardani, N. Mbay, \& A. Setiawan. 2019. Makassar strait throughflow seasonal and interannual variability: an overview. $J$. of
Geophysical Research: Oceans, 124(6): 3724-3736. https://doi.org/10.1029/2018JC01450 2

Jumars, P.A. 1994. Biological oceanography: an introduction (C.M. Lalli and T.R. Parsons). Limnology and Oceanography, 39(4):982-983. https://doi.org/10.4319/lo.1994.39.4.0 982

Kemili, P. \& M.R. Putri. 2012. Pengaruh durasi dan intensitas upwelling berdasarkan anomali suhu permukaan laut terhadap variabilitas produktivitas primer di perairan Indonesia. J. Ilmu dan Teknologi Kelautan, 4(1): 66-79. https://doi.org/10.29244/jitkt.v4i1.780 7

Kunarso, K., S. Hadi, N.S. Ningsih, \& M.S. Baskoro. 2012. Variabilitas suhu dan klorofil-a di daerah upwelling pada variasi kejadian ENSO dan IOD di perairan Selatan Jawa sampai Timor. Ilmu Kelautan: Indonesian J. of Marine Sciences, 16(3): 171-180.

https://doi.org/10.14710/ik.ijms.16.3. 171-180

Kunarso, M. Zainuri, R. Ario, B. Munandar, \& H. Prayogi. 2018. Impact of monsoon to aquatic productivity and fish landing at Pesawaran Regency Waters. IOP Conf. Ser.: Earth Environ. Sci., 116: 1-10. https://doi.org/10.1088/17551315/116/1/012021

Kuswardani, R.T.D. \& F. Qiao. 2014. Influence of the Indonesian throughflow on the upwelling off the east coast of South Java. Chinese science bulletin, 59(33): 4516-4523. https://doi.org/10.1007/s11434-0140549-2

Ningsih N.S., N. Rahkmaputeri, \& A.B. Harto. 2013. Upwelling variability along the southern coast of Bali and in Nusa Tenggara Waters. J. Ocean Science. 48(1):49-57. 
http://doi.org/10.1007/s12601-0130004-3

NOAA Climate Prediction Center. 2015. El Nino Southern Oscillation. Available at

https://www.cpc.ncep.noaa.gov/produ cts/precip/CWlink/MJO/enso.shtml

Nof, D., T. Pichevin, \& J. Sprintall. 2002. "Teddies" and the origin of the leeuwin current. J. of Physical Oceanography, 32(9): 2571-2588. https://doi.org/10.1175/1520-048532.9.2571

Pranowo, W.S., H. Phillips, \& S. Wijffels. 2005. Upwelling event 2003 along South Java Sea \& The Sea of Lesser Sunda Islands. J. Segara, 1(3): 116123.

Purba, M. 2007. Dinamika perairan selatan Pulau Jawa - Pulau Sumbawa saat Muson Tenggara. Torani, 17(2): 140150.

Quadfasel, D. \& G.R. Cresswell. 1992. A note on the seasonal variability of the South Java Current. J. of Geophysical Research, 97(C3): 3685-3688. https://doi.org/10.1029/91jc03056

Ratnawati, H.I., R. Hidayat, A. Bey, \& T. June. 2016. Upwelling di Laut Banda dan Pesisir Selatan Jawa serta Hubungannya dengan ENSO dan IOD. J. Omni-Akuatika, 12(3): 119139.

http://doi.org/10.20884/1.oa.2016.12. 3.134

Rosdiana, A., T. Prartono, A.S. Atmadipoera, \& R. Zuraida. 2017. Nutrient and chlorophyll - A distribution in Makassar upwelling region: From MAJAFLOX cruise 2015. IOP Conference Series: Earth and Environmental Science, 54(1): 1-9. https://doi.org/10.1088/17551315/54/1/012087

Santos, A.M.P., A.S. Kazmin, \& A. Peliz. 2005. Decadal changes in the Canary upwelling system as revealed by satellite observations: Their impact on productivity. J. of Marine Research, 63(2): 359-379. https://doi.org/10.1357/00222400536 93671

Sprintall, J., S. Wijffels, R. Molcard, \& I. Jaya. 2010. Direct evidence of the South Java Current system in Ombai Strait. Dynamics of Atmospheres and Oceans, 50(2): 140-156.

https://doi.org/10.1016/j.dynatmoce.2 010.02 .006

Sprintall, J., J. Chong, F. Syamsudin, M. Werner, S. Hautala, N. Bray, \& S.E. Wijffels. 1999. Dynamics of the South Java Current in the IndoAustralian Basin. Geophysical Research Letters, 26(16): 2493-2496. https://doi.org/10.1029/1999g1002320

Susanto, R.D., A.L. Gordon, \& Q. Zheng. 2001. Upwelling along the coasts of Java and Sumatra and its relation to ENSO. Geophysical Research Letters, 28(8): 1599-1602. https://doi.org/10.1029/2000GL01184 4

Stewart, R.H. 2008. Introduction to physical oceanography. Department of Oceanography, Texas A \& M University, Texas USA. 344 p. https://oaktrust.library.tamu.edu/hand le/1969.1/160216

Thomson, R.E. \& W.J. Emery. 2014. Data analysis methods in physical oceanography. Third Edition. Elsevier. 728 p.

Tranchant, B., G. Reffray, E. Greiner, D. Nugroho, \& R. Saint-Agne. 2015. Evaluation of an operational ocean model configuration at $1 / 12^{\circ}$ spatial resolution for the Indonesian seas. Part I: ocean physics, 8: 6611-6668. https://doi.org/10.5194/gmdd-8-66112015

Tubalawony, S. 2008. Dinamika massa air lapisan ekman perairan selatan JawaSumba Selama Muson Tenggara. Torani, 18(2): 148-159. 
Utama, F.G., A.S. Atmadipoera, M. Purba, E.H. Sudjono, \& R. Zuraida. 2017. Analysis of upwelling event in Southern Makassar Strait. IOP Conference Series: Earth and Environmental Science, 54(1): 1-8. https://doi.org/10.1088/17551315/54/1/012085

Utari, P.A., D. Setiabudidaya, M.Y.N. Khakim, \& I. Iskandar. 2019. Dynamics of the South Java Coastal Current revealed by RAMA observing network. Terrestrial, Atmospheric and Oceanic Sciences, 30(2): 235-245.

https://doi.org/10.3319/tao.2018.12.1 4.01

Wardani, R., W.S. Pranowo, \& E. Indrayanti. 2013. Vertical structure of upwelling - downwelling in South of Java and Bali Seas of the Indian Ocean based on seasonal salinity during a period of 2004 - 2010. Depik, 2(3): 191-199. https://doi.org/10.13170/depik.2.3.99 4

Wardani, R., W.S. Pranowo, \& E. Indrayanti. 2014. Variability of salinity related to ENSO and IOD in the Indian Ocean (South Java and Nusa Tenggara Seas) During Period of 2004-2010. J. Harpodon Borneo, 7(1): 9-18. https://doi.org/10.35334/harpodon.v7i 1.2

Xie, P. \& P.A. Arkin. 1997. Global precipitation: A 17-year monthly analysis based on gauge observations, satellite estimates, and numerical model outputs. Bull. Amer. Meteor. Soc., 78(11): 2539-2558. https://doi.org/10.1175/15200477(1997)078<2539:GPAYMA>2.0 .CO;2
Received : 13 January 2020
Reviewed : 28 February 2020
Accepted : 10 April 2020 